\section{SOI: $\underline{1.1 / \text { TAS }}$ DOI: $10.15863 /$ TAS International Scientific Journal Theoretical \& Applied Science}

p-ISSN: 2308-4944 (print) e-ISSN: 2409-0085 (online)

Year: 2015 Issue: 03 Volume: 23

Published: $30.03 .2015 \quad \underline{\text { http://T-Science.org }}$

\section{William Smith}

researcher of National Museum of Natural History, Smithsonian Institution,

Washington, USA

EInur Latif oglu Hasanov Corresponding member of International Academy of Theoretical and Applied Sciences, Ph.D. postgraduate Institute of Local-lore of Ganja Branch Azerbaijan National Academy of Sciences, Ganja, Azerbaijan 1-hasan@hotmail.com

SECTION 12. Geology. Anthropology. Archaeology.

\title{
ABOUT CULTURAL-ETHNOGRAPHICAL DESCRIPTION OF TRADITIONAL DECORATIVE-APPLIED ARTS OF GANJA
}

\author{
Abstract: On the basis of Azerbaijan-USA scientific investigations have been researched the innovative \\ arguments and facts about development of the main historic-ethnographical and cultural features of local kinds of \\ decorative-applied arts of Ganja city. \\ Key words: decorative-applied art, Ganja, culture, historic-ethnographical research. \\ Language: English \\ Citation: Smith W, Hasanov EL (2015) ABOUT CULTURAL-ETHNOGRAPHICAL DESCRIPTION OF \\ TRADITIONAL DECORATIVE-APPLIED ARTS OF GANJA. ISJ Theoretical \& Applied Science 03 (23): 33 - \\ 36. \\ Soi: http://s-o-i.org/1.1/TAS*03(23)6 Doi: crossef http://dx.doi.org/10.15863/TAS.2015.03.23.6
}

\section{Introduction}

Ganja is one of the richest areas from archaeological point of view. As a result of archaeological investigations here were found samples of material culture that concerned to the stages of different history period. Today most of them are kept in various museums of the world. The flint tools, that found in Gillikdag workshop and camp around Ganja, ladle, that were found by a prominent Azerbaijani archaeologist Isag Jafarzade, give the reason to say, that people, who lived in this area in VII - VI millennium BC were the founders of the Late Stone Age culture. Archaeological investigations prove that in this period the main population of this region had sedentary lifestyle and were engaged with farming.

During middle ages in spheres of gentle and applied art, Ganja of inhabitants of territory, in agriculture life bone was widely applied. Bone products, raw materials that found during investigations in and around Ganja prove, that time bone processing separated from other spheres of craftsmanship. Osteology analysis prove, that most of samples are prepared from the bone of bull, caw, deer among big horde animals and sheep, goat, boar among little horde animals. Only deeding investigations in Mingechaurs there were found a lot of samples of combs, agriculture instruments, art and other bane things. Such kind of bone samples also were found in monument complexes territory of Injachay and Kerpicli in Goranboy region during excavation. Art samples and dice for playing nard, found in territory Shatal, also attracts our attention. These samples of art make more ancient history of city culture of Azerbaijan and in whole play nard .There were found knife handles, rare geometrical decorations, samples of pipe and other instruments here. During excavations there was found bone products that used as raw materials and cutting with pipe. In XI- XIII centuries this sphere of art was developing mostly. This thought is proved with a lot of bone and horn, found in zone of excavation. This period from bone there were prepared buttons, knifes and etc. Found during archeological excavations and used in wooden treatment and knife, showed that at the beginning of XI - XIII in and around Ganja this sphere of craftsmanship in exist. Bone boards with circular surface molding decoration decoration were found in Mingechaur, in Khogali barrow № 2, Sarichoban, Borsunlu and others. Monument, that including to Borsunlu Complex is finishing with small wheel desk from bone and two omlets, prepared from teeth of boar. In this period also were prepared such kind of agriculture instruments as wood shovel, rake and etc. But they didn't reach nowadays [1]. 


\section{Materials and methods}

Along with the works and notes of medieval authors and travelers, a lot of material samples, found in the territory of ancient Ganja, also found in Mingachevir and concern to Middle Ages trough, ladle, wooden threshing board, shows that in Ganja wood treatment and sculptor art have a rich tradition.

Wood treatment products historically have been represented in various fields of social and cultural life in Ganja:

1. Kitchen appliances: trough, quadruped, rolling-pin, mortar and pestle, ladle, spoon, trough.

2. Transport means: sleigh, car, and ski.

3. Weaving tools: comb, face.

4. Household tools: harrow, wooden plow,threshing board, spade, wooden shouvel, pitchfork, rake.

5. Musical instruments: saz, ud, tar, chamahcha, tambourine, drum.

\section{Main aims of research}

Along with the mosque Juma (Shah Abbash), that constructed in 1606, local samples of trade ornamentals, that built in Sheikh Javad Khan Street, that have 3 century history and was built in the nineteenth century in building of Sheikh Nizami Ganjavy's (1141-1209) representatives Sheikhzamanlylars property and, that was restored in 2011, are attractive especial attention [5].

The craftsmanship of carpet-making is one of the important cultural achievements of the Eastern people in Azerbaijan production of carpets appeared during I millennium BC. But carpet-making in the first period of Middle Ages has turned to the independent sphere of craft. In Ganja, that has minimum 4000 years history, production of carpets differed with quickly development. In this ancient city, that is native land of great Azerbaijani poet and thinker Sheikh Nizami Ganjavi, were weaved very uncial, inimitable kinds of carpet. In Ganja, that has rich traditions, were prepared carpets with various characteristics. For this reason one of Azerbaijani carpet groups are Ganja carpets or (Ganja-Kazakh carpets).Pay attention that in Ganja namely local kinds of carpets-palaz (carpets without of pile) are weaved [6]. These carpets that are producing by local inhabitants are differing with specific handicraft features:

1. Ganja carpets are differing with pile.

2. Thickness indicators of such kind of carpets with comparaturly small number attract attention.

3. Composition is more distinct and simple.

4. Most of ornamental patterns have geometrical features.
5. In coloring carpet samples were used bright colors.

6. Local carpet masters skillfully used buta's amatively patterns [6].

The size of Ganja's carpets begins from 3 square meters to 10 square meters. There are 2 important carpets groups exist:

1. Ornamental carpets.

2. Carpets with a plot.

Majority of local wool products, richness of natural colors and existence professional carpetmaking women made for quick development carpet making craftsmanship in Ganja and in its surround territories.

Just only in 1845 year there were produced 2969 carpets in Ganja. Among them products of 1784 manats have been exported. Also, from Ganja province there were exported 23 thousand pod in 1886,30 thousand 275 pod in 1889,33 thousand 156 pod in 1893, and 37 thousand 228 pod in 1913 carpets by railway. One part of these qualitative Ganja carpets has been transported with Batumi part top Turkey to Istanbul, and from there to West Europe and North America [7].

In whole at the beginning of IX- XX century the quality of carpet craftsmen were more than XX thousand. At the result of it during a lot of years were prepared such kind of qualities carpets as "Kohne Ganja"("Old Ganja"), "Phahrali", "Chiraqli", "Chayli", "Samukh", "Zeyva", "Sarisi","Shadilli". In this period in Ganja were produced as carpet with pile, also carpets without pile. Such kind of carpets without pile as phalas, kilim, holdall, bead, verni, sumach, heybe, carpet - bag were different with qualities and colored ornamental elements. Especially we must say that Ganja carpets have always been valued for its quality and art characteristics. As the result of in IX - XX centuries most of Ganja carpets were showed in world in fluent exhibition. In 1850, 1852 and 1912 years in Tbilisi, in 1896 - in Nijni Novgorod, in 1900 year in Paris, in 1911 year in Turn Ganja carpets were showed and highly in international exhibition. Nowadays, Ganja's carpets are kept in authoritative museums of world, and also in collection of different people. The studying of Ganja's carpets for art characteristics quality form science point of view is very important for investigation heritage of world culture [8].

\section{Results and discussion}

History and art of Azerbaijan people as rich and colorful as its nature. On decorations of this descriptive art are reflected spiritual world, living style, customs and traditions of our nation. These pearls of art on material preparing and processing techniques are divided into different kinds. Among these types of craft metal treatment is mostly 
developed and has ancient history. Abundance of local raw materials created favorable conditions for development of metal treatment from ancient times. In general, in the third millennium $\mathrm{BC}$ there was high culture of the Bronze Age in our country, and in the first millennium transition period from Bronze Age to Iron Age began. In that period in Azerbaijan there were appeared several branches of metallurgy treatment. Jewelries, daggers, arms, copper products and other samples of art have been treated so refined, that in nowadays they are protected as very valuable exhibits in famous museums in such cities, as Paris, London, Brussels, Istanbul, Tehran and other cities.

\section{Conclusion}

Works of art, made from metal, for their content and their form are divided into two major groups:

1) Products of art;

2) Household goods.

Household equipment, works of art, agriculture instruments, that made by Ganja crafts, have been executed into two main technical methods:

1) Casting

2) Forging

In the first half of the XVIII-XIX centuries, as well as in other parts of Azerbaijan, in Ganja household objects, forging weapons and jewelries that made from metal were decorated with different technical ways. As in many places, production of wool, cotton and silk in and around Ganja made necessary emergence and development of weaving. In traditional production of cloth manufactory trade historically played an important place. This kind of craft that developed on the basis of local raw materials was tied with cotton-growing economy. Since the time of the early Middle Ages, Ganja as Tabriz, Ordubad have been the main center of Azerbaijan in production of cotton cloth. In this ancient city printed cotton and calico fabrics have been widely produced. In traditional cloth productions the main place took the urban mines [12].

The formation of pottery on the territory of ancient Ganja is concern to the stages of ancient history. Basis on research works carried out by the various persons in XIX century and expertsarcheologists at the beginning of XX century in old ruins of the city and surrounding areas there were found different samples of pottery. First of all, there have been discovered, that initial ceramic production in Ganja and its surrounding regions are belong to the VIII-VII millennium BC.

From the history point of view, these ancient clay vessels, belonging to the Neolithic stage, are differing from the pottery samples of the neighboring ethnic in number characteristics. These differences are seen in preparing technology, also in the area of external surface decoration. From the construction point of view, samples of pottery, that concern to Antique period, also to the period of Hellenism in Ganja, differed in various forms as pictorial vases, ceramic figures, connected dishes. During the end of Middle Ages and New Period in Ganja and its regions ceramic has following kinds as building ceramic materials, unglazed ceramic products, glazed ceramic products. For Middle Ages and New period among pottery products of Ganja ceramic samples as clay construction materials have great importance. First of all, glazed bricks that used in construction of most buildings in the XVII-XVIII centuries, and also in great monuments and the main construction material- air-dried bricks, attracted attention. In addition to the found samples in residential areas as a result of archaeological excavations, also were found a lot of brick spoilages. According to such kind mass finding of brick spoilages, we can make the conclusion, that the bricks used in construction of buildings in Ganja, were wares of local production [8-11].

\section{References:}

1. Guliyeva NM, Hasanov EL (2012) About ethnographic-archaeological research of some handicraft branches of Ganja during XIX - XX centuries / Progressive scientific explorations 2012: Proceedings of the 8th International scientific-practical conference. Prague: Publishing House - Education and Science s.r.o., pp.73-75

2. (1974) The dawn of Art. Leningrad: Aurora Art Publishers, $196 \mathrm{p}$.
3. Guliyeva NM, Hasanov EL (2012) New ethnographic approach to the research of main decorative - applied arts of Ganja of the XIX $\mathrm{XX}$ centuries / International scientific conference - Achievements in science: new views, problems, innovations. Lodz, pp. 56-58

4. (1853) Kavkazskiy kalendar' na 1854 g. Tiflis, 1853. - pp. 338-341

5. Həsənov EL (2012) Gəncə İmamzadə türbəsi (tarixi-etnoqrafik tədqiqat). Bakı: Elm və təhsil, $268 \mathrm{p}$. 
6. Häsänov EL (2012) Die Gändschänischen teppiche von XIX - XX Jahrhundert als geschichtliche - ethnographische quelle / European Science and Technology (Die Europäische Wissenschaft und die Technologien): 2nd International scientific conference. Bildungszentrum Rdk e. V. Wiesbaden, pp. 26-27

7. (2008) Azərbaycan arxeologiyası: 6 cilddə, VI cild, Bakı: Şərq-Qərb, 2008. - 632 p.

8. Kulieva NM, Gasanov EL (2011) O razvitii khudozhestvennoy keramiki $\mathrm{v}$ drevney Gyandzhe / Materialy mezhdunarodnoy zaochnoy nauchno-prakticheskoy konferentsii Voprosy obshchestvennykh nauk: sotsiologiya, politologiya, filosofiya, istoriya. Novosibirsk: Apriori, pp. 132-135

9. Hasanov EL (2012) Innovational ethnographic facts on investigation and teaching of some basic decorative - applied arts of Ganja of the XIX - XX centuries / Applied and Fundamental Studies: Proceedings of the 1st International Academic Conference. Saint Louis: Publishing House - Science and Innovation Center, Missouri (the United States of America). pp. 400-403

10. Alieva AS (1973) Vorsovye kovry Azerbaydzhana XIX - nach. XX vekov. Baku: Elm, 1973. - pp. 21-25.

11. (2007) Azərbaycan etnoqrafiyası: 3 cilddə, I cild, Bakı: Şərq-Qərb, 2007. - 544 p.

12. Hasanov EL (2015) Aspetti Culturali della Ricerca delle Tradizioni Artigianali di Ganja dei Secoli XIX-XX. Mediterranean Journal of Social Sciences, vol. 6, № 2, part 1, pp. 372375. doi:10.5901/mjss.2015.v6n2s1p372 